\title{
PROSES KREATIF PERUPA I MADE SUPENA
}

I Gde Suryawan

Fakultas Bahasa dan Seni Universitas Pendidikan Ganesha Bal email : de_Suryaoneart@yahoo.co.id

\section{Abstrak}

Penelitian ini bertujuan untuk memperoleh gambaran tentang (1) Biografi Supena, (2) Konsep karya Supena, (3) Proses kreatif Supena, (4) Periodisasi karya Supena, dan (5) aspek teks hingga konteks pada karya Supena. Penelitian ini merupakan penelitian kualitatif. Pengumpulan data dilakukan dengan teknik observasi, wawancara, dan telaah dokumen terhadap proses kreatif I Made Supena. Hasil penelitian sebagai berikut. (1) Supena adalah salah satu perupa dari Singapadu, Bali. Ia berasal dari keluarga seniman. Ayahnya, I Ketut Muja, adalah seorang pematung. Kakaknya, I Wayan Jana, juga seorang pematung. Adiknya, I Ketut Sugantika, adalah seorang pelukis. Sementara itu iparnya, Ni Nyoman Sani, merupakan seorang pelukis. (2) Konsep karya Supena adalah menggali persoalan alam dan kehidupan untuk direpresentasikan secara formalistik. (3) Selain melukis Supena juga mengembangkan gagasannya dalam bentuk patung, instalasi, dan Performance Art. Sebagai seorang perupa Supena lebih memilih bekerja secara individual. (4) Priodisasi karya Supena adalah tradisional, formalistik, dan emosi. (5) Karya Supena dapat dibaca berdasarkan pendekatan teks yang menyangkut unsur-unsur seni rupa dan nilai estetis yang terkandung dalam karya, serta dapat pula dibaca konteksnya dengan menarik pemaknaan yang ada dibalik teks karya Supena.

Kata kunci : biografi, konsep, proses kreatif, periodisasi, teks dan konteks

\section{THE CREATIVE PROCESS OF I MADE SUPENO}

\section{Abstract}

This study aimed to obtain the description of (1) the biography, (2) the concept, and (3) the creative process of Supena's works, and also reveal (4) the division of historical periods and (5) the aspects of text and context in his works. This is a qualitative research with the data collection process using observation, interview, and document analysis techniques. The subject of this research is the creative process of I Made Supena. The findings of this study reveal that (1) Supena is one of the artists from Singapadu, and he was born in a family of artists. His father, I Ketut Muja, is a sculptor, while his elder brother, I Wayan Jana, is also a sculptor. His younger brother, I Ketut Sugantika, as well as his sister in law, Ni 
Nyoman Sani, who is the wife of I Ketut Sugantika, is a painter. (2) The concept of Supena's works is to describe about the problems in his nature and the life issues which are then represented in formalistic ways. (3) Besides painting, Supena also develops his ideas in the forms of sclupture, installations and art performance. As an artist Supena prefers working individually meaning that he uses the principle of self-management in the process of his artistic performances and activities. (4) The division of historical periods in Supena's works reveal that his works belong to traditional, formalistic, and emotional groups. (5) The works of Supena are readable through text-based approach that involves the elements of art and aesthetic values embodied in the work itself, and they can also be read by understanding the contextual meanings behind his works.

Keywords: biography, concept, creative process, historicsl periods, text and context

\section{PENDAHULUAN}

Bali memiliki banyak kekayaan seni rupa. Seni rupa Bali tumbuh sangat pesat, baik seni rupa tradisi, modern, maupun kontemporer. Proses regenerasi yang dinamis menjadikan seni rupa Bali tetap eksis dan memiliki pewarisnya masingmasing. Ia tumbuh dalam masyarakat komunal yang mendukungnya. Dalam perkembangannya, banyak desa menjadi pusat pengembangan kegiatan seni rupa, salah satunya adalah Singapadu.

Singapadu, desa di kawasan Sukawati Gianyar Bali, memiliki sejarah panjang dalam dunia kesenian, khususnya seni rupa. Di desa ini terlahir banyak seniman, mulai dari yang otodidak hingga yang menempuh jalur akademik dalam bidang seni rupa. Singapadu juga melahirkan sanggingbarong (pematung tradisional) sekaligus perupa kontemporer. Cokorda Raka Tisnu dan Cokorda Alit, yang lebih dikenal sebagai pematung Muja dan pegiat seni rupa tradisional, merupakan contoh dua orang seniman yang lahir dari desa ini.

Selain dua orang seniman di atas, salah satu perupa kontemporer yang banyak diperbincangkan dalam dunia seni rupa kontemporer Bali adalah I Made Supena. Ia anak dari Muja, seorang pematung asal Singapadu. Tidak seperti sang ayah yang dikenal sebagai pematung, I Made Supena dikenal sebagai pelukis. Namun, dalam karya-karya terbarunya, Supena juga membuat patung sebagai bagian dari karya instalasinya.

Supena memulai kesenimanannya dengan menempuh pendidikan formal seni rupa di Program Studi Seni Rupa dan Desain (PSSRD) UNUD pada 19911997. Ia mulai aktif berkarya dan mengikuti banyak pameran, baik berkelompok maupun tunggal. Pada 9 April 1996, I Made Supena bersama beberapa seniman yang merupakan mahasiswa dari PSSRD UNUD dan STSI Denpasar, seperti
Setem, Sudana, Dewa Soma Wijaya, Diwa Rupa, Naya Swantha, Ketut Teler, Made Ardika, dan Galung Wiratmaja, mendirikan kelompok bernama Galang Kangin. Kelompok ini aktif menyelenggarakan beberapa pameran, performance art, dan diskusi-diskusi kesenirupaan. Selama dua puluh tahun berkarya, Supena mengelompokkan perjalanan berkaryanya dalam tiga periodisasi. Periode-periode tersebut oleh Supena dinamai sebagai periode tradisi, periode formal, dan periode emosi. Periodisasi tersebut bukan sebagai retrospektif, tetapi lebih menandai segala yang sudah dilakukannya.

Pertama, periode tradisi. Pada periode ini garis merupakan pijakan awal dari karya-karya Supena. Ia mengambil bentuk-bentuk wayang tradisional I Gusti Nyoman Lempad. Supena menganggap bahwa memberikan makna pada unsurunsur karya seni rupa sudah dianggap cukup. Selain unsur garis, unsur tradisi, seperti nilai-nilai dan bentuk-bentuk seni rupa tradisi (barong dan topeng), hadir sebagai inspirasi dari karya-karya Supena.

Kedua, periode formal dan presentasi. Pada periode ini Supena lebih menonjolkan aspek estetika formalisme sebagai pijakan karyanya. Unsur-unsur seni rupa seperti garis, warna, bidang, komposisi, tekstur, digali dan dipresentasikan dalam karya-karyanya yang menjadikan alam sebagai pijakan utama kekaryaannya. Pada karya ini teks rupa terkadang menjadi teks murni. Namun, tidak jarang ia dapat pula terbaca sebagai representasi alam. Karya-karya dalam periode ini, antara lain Landscape, Rentetan, serta seri lukisan Borobudur. Karya-karya Supena bergulat dan memaknai secara mendalam teks-teks rupa dengan meminjam objek-objek yang kemudian dapat dibaca sebagai representasi alam.

Ketiga, periode emosi. Pada periode ini karya-karya Supena hadir sebagai representasi atas kegelisahannya dalam memandang realitas sosial yang terjadi di masyarakat yang sedang bergejolak. Fenomena sosial-fenomena sosial tersebut, seperti gejala bunuh diri, konflik horizontal, dan carut-marut dunia politik. Secara emosional Supena terdorong menciptakan karya-karya tidak terbatas pada lukisan, tetapi juga karya tiga dimensional. Karya-karya dalam kelompok ini bersifat figuratif representasional. Artinya, ia tidak sebatas meminjam objek seperti pada kelompok formal tetapi juga memaknai objek itu sebagai ungkapan emosinya atas fenomena sosial yang terjadi di masyarakat. Pada periode ini terwujudlah beberapa karya lukisan, drawing, dan ratusan patung yang kemudian dipersentasikan menjadi karya-karya instalasi.

Melihat periodisasi dan perkembangan Supena dalam berkarya, terlihat bahwa ia merupakan salah seorang perupa penting dalam dunia seni rupa kontemporer Bali. Sebagai perupa, Supena cukup konsisten dalam mengembangkan karier kesenirupaannya. Sejak awal karier hingga kini, ia telah mengikuti beberapa pameran, baik berkelompok maupun tunggal. Sejak 1991-2009 ia tercatat telah 
mengikuti kurang lebih sembilan kali pameran tunggal, baik di Bali, Surabaya, maupun Jakarta. Pada tahun 2000 ia sempat pameran bertajuk Landscape Und Abstarction di Kota Frankfurt, Jerman. Disamping itu, Supena juga telah berpatisipasi dalam puluhan pameran bersama selama hampir 20 tahun karier kesenirupaannya.

Supena memperoleh beberapa penghargaan dari lembaga kebudayaan baik bersekala lokal, Nasional dan Internasional. Penghargaan-penghargaan tersebut, antara lain Philip Moris Art Award di Jakarta, Award of Excellence Bali, dan Prience Edward Island Canada. Selain berkiprah dalam dunia seni rupa kontemporer, Supena juga terlibat dalam beberapa aktivitas sosial. Ditengah kesibukannya sebagai perupa, Supena juga aktif dalam membangkitkan semangat para perupa Singapadu untuk berkiprah dalam dunia seni rupa kontemporer. Salah satu upaya itu adalah dengan menghimpun para perupa Singapadu yang terdiri dari para pelukis dan pematung untuk membentuk komunitas. Karya-karya mereka dipamerkan digaleri Santrian Sanur, pada 30 Oktober 2009. Pameran tersebut diselenggarakan dengan kurator Thomas U Frientag, seorang sejarawan seni asa Jerman yang telah lama bekerja sama dalam mengurusi karya-karya Supena.

Karya-karya Supena digali dari persoalan alam dalam kemasan formalisme estetik yang kuat, sehingga karya-karya tersebut pada periode abstrak merupakan representasi alam yang menyajikan tampilan karya yang kaya akan nilai estetis disamping pemaknaan yang dijanjikan dalam lukisannya. Selain alam, konsep karya Supena juga berkaitan dengan narasi sosial, terutama pada periode emosi yang banyak melukiskan anak-anak. Karya-karya pada periode tersebu merupakan representasi atas fenomena yang melanda sebagian anak-anak Indonesia, seperti bunuh diri dikalangan anak-anak, gizi buruk, dan mahalnya biaya pendidikan.

Proses kreatif Supena dimulai dari proses pencarian ide. Setelah itu, ide yang diperoleh dituangkan dalam bentuk sketsa untuk dipindahkan dalam kanvaskanvasnya. Selain melukis Supena juga menghadirkan karya-karya patung. Hal ini tidaklah mengherankan karena Supena mewarisi keahlian mematung dari ayahnya, I Ketut Muja. Karya-karya patung Supena juga hadir sebagai instalas yang dipresentasikan bersama dengan karya lukisnya. Dengan demikian, instalas Supena merupakan pengembangan dari kemampuan melukis sekaligus mematungnya. Supena juga menghadirkan beberapa karya performance untuk merespon karya instalasinya. Akibatnya, antara instalasi dan performance merupakan satu kesatuan.

Supena merupakan perupa yang menghadirkan hasil karyanya sebaga pernyataan personal. Karya-karya Supena menjanjikan pembacaan terhadap teks, nilai estetis yang secara kasat mata dapat dilihat oleh penikmat, dan terhadap konteks karya, yang merupakan suatu gagasan yang terkandung di balik setiap karya-karyanya. Dengan demikian, karya Supena memiliki sifat representatif yang dihadirkan melalui jalan puitis melalui bahasa rupa yang personal dan dalam.

Atas dasar itulah penulis merasa tertarik untuk menggali dan melakukan pembacaan terhadap biografi, konsep kreatif, proses kreatif, teks, dan konteks yang melekat pada karya-karya Supena. Penelitian ini juga dimaksudkan sebagai pendokumentasian kiprah kesenimanan Supena sebagai salah seorang perupa kontemporer Bali. Dengan demikian, tulisan ini diharapkan mampu menjadi sumbangan dokumentasi ditengah langkanya penelitian tentang para perupa kontemporer Bali.

\section{METODE PENELITIAN}

Penelitian ini merupakan penelitian deskriptif kualitatif terhadap karyakarya I Made Supena,yang meliputi karya-karya dua dimensi (lukisan) dan karyakarya tiga dimensi (instalasi dan patung). Jadi, subjek penelitian ini adalah karyakarya I Made Supena. Dalam mendapatkan dan mengumpulkan data, peneliti memakai instrumen penelitian berupa alat yang bisa merekam secara visual dan (atau) audio, yaitu kamera serta perekam suara. Pemeriksaanya berdasarkan foto dokumentasi, video dokumentasi, atau audio dokumentasi.

Karya-karya Supena tidak hanya dibaca dengan pendekatan tekstual semata (unsur-unsur rupa) tetapi juga melalui pendekatan kontekstual (muatan). Penelitian ini akan memaparkan tentang perupa I Made Supena yang meyangkut biografi, konsep kreatif, proses kreatif, periodisasi, teks dan konteks. Pemaparan tersebut berdasarkan pada konsep seni rupa tradisional, modern, kontemporer, biografi, serta semiotika dan estetika.

\section{HASILDAN PEMBAHASAN}

Singapadu adalah salah satu desa di Bali yang kaya dengan aktifitas kesenian, seperti seni tari, seni karawitan, dan seni rupa. Khusus di bidang seni rupa, desa ini dikenal sebagai pusat pembuatan topeng barong dan rangda yang cukup dikenal di Bali. Singapadu banyak melahirkan perupa, mulai dari yang otodidak hingga yang menempuh jalur akademis. Salah satu perupa akademis itu terlahir pada 12 Januari 1970 dari pasangan suami istri I Ketut Muja dan I Made Robin. Perupa itu adalah I Made Supena.

Sejak kanak-kanak Supena telah akrab dengan dunia kesenian, khususnya seni patung. Suara-suara pengotok dan pahat yang menghunjam batanganbatangan kayu telah terbiasa didengarnya. Hal ini sangat wajar, karena Supena terlahir dari keluarga seniman. Sang kakek, I Nyoman Doblogan, seorang undagi dan pematung. Sementara sang ayah, I Ketut Muja, adalah pematung yang handal dan terkenal lewat patung hanomannya. Patung Hanoman Muja memiliki ciri khas tersendiri seperti ekspresi gerak patung yang atraktif dan terkadang menonjolkan 
karakteristik kayu, misalnya dari segi serat dan bentuk kayu itu sendiri. Di dalam lingkungan keluarga yang seperti itulah darah seni Supena kecil terbentuk.

Jejak kesenimanan Supena dimulai sejak usia kanak-kanak. Setelah ia memasuki bangku sekolah menengah, Supena memutuskan menempuh pendidikan di SMIK, sekarang berubah menjadi SMK 2 Sukawati. Ia memilih program keahlian seni kriya kayu. Pada tahun 1991-1997 Supena melanjutkan studi di FSSRD Universitas Udayana mengambil Jurusan seni lukis.

Di kampus ia berhadapan dengan kaidah-kaidah akademik yang diserapnya dalam proses berkarya. Selama kuliah Supena mendapatkan ilmu serta wawasan seni rupa secara utuh. Ia menyerap segala bentuk kaidah-kaidah estetik barat, seperti komposisi, pewarnaan, keseimbangan, dan kesatuan. Kaidah-kaidah tersebut berpengaruh terhadap kecenderungan karyanya yang menunjukan kekuatan formalis.

Perjalanan kuliah Supena mengalami berbagai macam cobaan, salah satunya ketika ia mengalami kecelakaan berat, sehingga Supena terpaksa berhent beraktivitas selama setahun. Kondisi tersebut mempengaruhinya. Supena menjadi lebih tertutup dan merasa kesepian. Namun, hal ini tidak berlangsung lama. Supena akhirnya bangkit kembali dan berusaha untuk merintis karier kesenimanannya dengan mulai mengikuti beberapa pameran. Pada tahun 1991 , Supena mulai berpameran untuk pertama kalinya pada kegiatan Pesta Kesenian Bali (PKB) di Taman Budaya Denpasar. Dari sanalah awal Supena merintis karier di bidang seni rupa. Setelah itu, ia silih berganti mengikuti berbagai pameran, baik tunggal maupun berkelompok.

Salah satu upaya Supena untuk mengembangkan eksistensi diri dan kawan-kawannya, sesama perupa muda, adalah dengan menghimpun diri dalam kelompok yang diberinya nama Galang Kangin. Kelompok ini terdiri dari orangorang muda yang merupakan seniman-seniman lulusan dua perguruan tinggi berbeda, yaitu FSSRD (Unud) dan STSI Denpasar (kini ISI Denpasar). Di dalam catatan, kelompok ini berdiri pada 9 April 1996 dengan anggota terdiri dari I Made Supena, I Dewa Gede Soma Wijaya, I Wayan Naya Swantha, Galung Wiratmaja (FSSRD Unud), I Wayan Setem, I Ketut Teler, I Nyoman Diwarupa, I Made Ardika (petruk), dan I Made Sudana (koplek) (STSI Denpasar). Pada saat terbentuknya kelompok ini, Galang Kangin diketuai I Wayan Setem.

Pendirian kelompok Galang Kangin dilatarbelakangi oleh berkembangnya isu-isu penggabungan dua institusi seni, yaitu Program Studi Seni Rupa dan Desain (PSSRD) Universitas Udayana dan Sekolah Tinggi Seni Indonesia (STSI) Denpasar. Banyak kalangan tidak menyepakati penggabungan itu karena latarbelakang dan sistem yang dianggap tidak sama. Untuk menepis opini yang menganggap penggabungan itu sebagai hal yang sulit, sejumlah mahasiswa dari dua institusi itu mendahuluinya menjawab bahwa mereka dapat "seirama" dalam menjaga visi kesenian.

Galang Kangin disepakati sebagai nama komunitas itu. Nama tersebut berarti “cahaya diufuk timur." Dalam pemahaman yang luas, Galang Kangin dapat dimaknai sebagai memulai sesuatu dengan benar berdasarkan permulaan waktu kerja. Ketika fajar mulai merah di ufuk timur, ia merupakan sebintik cahaya yang sehat, hangat, dan segar. Nama itu dapat juga diartikan sebagai kebijaksanaan atau pengetahuan dari timur.

Supena sendiri memiliki kesadaran sosial yang tinggi terhadap desanya. Hal itu ia tunjukkan dengan mendirikan sebuah kelompok yang menaungi para perupa di Singapadu, baik pelukis, pematung, pembuat topeng, maupun sangging barong. Mereka berasal dari segala lapisan usia, baik yang muda maupun yang sudah senior. Kelompok itu diberi nama Perupa Singapadu dan diketuai sendiri oleh Supena. Kelompok ini mengadakan pameran perdananya di Gallery Santrian Sanur, pada 30 Oktober 2009.

Supena terus menapaki perkembangan kekaryaannya. Suami dari Ni Wayan Sukantri (33 tahun) serta bapak dari tiga orang putra-putri, yaitu Ni Putu Sanjiwani (11 tahun), Ni Made Laras Wangi (9 tahun), dan I Komang Bayu Gana Arta (3 tahun) ini selalu berkarya untuk memenuhi hasrat estetikanya. Menurut Supena kesenian merupakan kebutuhan jiwa. Oleh karena itu, pada setiap kesempatan Supena selalu berada di studio, yang sekaligus menjadi rumahnya di Banjar Mukti, Singapadu, Gianyar. Iklim berkesenian sangat terasa di studio. Di tempat itu ia tidak bekerja sendiri. Bersama ayah, kakak, adik, dan iparnya, Supena terus mengembangkan kreativitasnya, baik secara individu maupun sebagai sebuah keluarga seniman.

Sang ayah, I Ketut Muja (66 tahun), merupakan seorang pematung senior yang dimiliki Desa Singapadu. I Ketut Muja dikenal sebagai spesialis pematung Hanoman yang memiliki kecenderungan ide penggarapan dengan konvensi tradisi. Ia memiliki gaya atau corak khas yang kemudian menjadi identitas dirinya. Di samping itu, ia juga sering membuat patung dengan mengekspos karakter struktur bahan, yaitu kayu sebagai media utama. Ia membiarkan bentuk asli kayu sebagai struktur-struktur dasar bentuk patungnya, sehingga sekilas patungnya tampak ganjil, magis, dan memiliki nafas-nafas surealistik.

Saudara Supena yang paling sulung, I Wayan Jana (42 tahun), juga memiliki kecenderungan berkarya seni patung. Perupa yang pernah mengenyam pendidikan di ISI Yogyakarta (1990-1992) ini hadir dalam karya-karya yang akademis. Ia menyerap kaidah-kaidah estetika patung modern, terutama corak figuratif yang khas seperti penghadiran figur-figur wanita yang telah mengalami distorsi dan stilirisasi. Hal tersebut terjadi karena pengaruh dari dunia akademi yang pernah ditempuhnya. Tak seperti patung sang ayah yang terkesan magis dan religius, patung Jana terasa elegan, figuratif, dan mengalami stilirisasi. Bentuk 
yang mengesankan formalisme estetik terlihat pada figur-figur perempuan yang mengalami penyederhanaan bentuk, sehingga patung Jana terlihat lebih minimalis.

Adik Supena yang menekuni seni lukis adalah I Ketut Sugantika. Ia akrab disapa Lekung oleh kawan-kawannya. Sugantika adalah anggota dari kelompok Hitam-Putih. Tak seperti sang kakak yang lebih menekuni abstrak, Sugantika memiliki kecendrungan rupa yang realis. Sugantika merupakan pelukis muda yang dikenal sering mengangkat bentuk-bentuk babi sebagai "ikon" dalam karyanya. Ia juga sering melakukan eksperimen visual melalui karya instalasi lukisan. Salah satu karyanya berjudul Mengatur Pikiran berupa penggabungan karya lukis dan video.

Sang ipar, Ni Nyoman Sani kelahiran Sanur, yang merupakan istri dari Sugantika juga menekuni seni lukis. Karya-karya Ni Nyoman Sani menyangkut figur-figur wanita dalam baluran fashion. Karyanya terkesan sederhana non-realis dan mengalami distorsi bentuk. Sani tergabung dalam kelompok Hitam Putih. Dari gambaran di atas terlihat bahwa Supena memang berada dalam lingkungan seniman yang kuat.

Supena adalah perupa yang telah malang melintang di dunia seni rupa Bali. Supena telah melakukan berbagai pameran baik pameran tunggal maupun pameran bersama. Tidak kurang dari sembilan kali pameran tunggal pernah digelarnya baik di Bali, Jakarta, Yogjakarta, maupun luar negeri. Pada 1998 ia mulai pameran tunggal perdananya di Gallery The Chendi Payangan Gianyar Bal dan kemudian disusul pada pameran tunggal keduanya pada 1999 yang berjudul Reality of Abstract Painting di Taman Budaya Art Center Denpasar. Pada tahun 2000 Supena dan kawannya, Susena, berkesempatan mengadakan pameran berdua di Frankfrut Jerman dalam sebuah pameran yang bertajuk Landscape UndAbstraction.

Pada 2002 Supena mengadakan dua kali pameran tunggal, yaitu di Suli Art Gallery Denpasar dengan tajuk New Painting. Setelah itu, pameran di Gallery Moon Décor Jakarta bertajuk About Nature. Berikutnya pada 2004 ia pameran tunggal di Ganesha Gallery Jimbaran Bali bertajuk The Likeness of Nature. Pada 2005 ia pameran di Danes Art Veranda Denpasar berjudul Studi Alam Supena. Pada 2007 ia merambah kota Surabaya tepatnya di Gracia Gallery dengan judu pameran Landscape I Made Supena. Setahun kemudian ia menghadirkan pencapaian kreatifnya di Santrian Gallery Sanur. Saat itu, ia menyelenggarakan pameran berjudul Emotion. Pada 2010 Supena memamerkan karya-karyanya di Jogja Gallery dengan judul Geneologi.

Tidak hanya pameran tunggal yang telah digelar, pameran bersama pun sangat sering diikutinya. Kurang lebih 59 kali Supena mengikuti pameran bersama. Sejak 1991 dan 1992 ia mengikuti pameran bersama dalam Pesta
Kesenian Bali (PKB) di Taman Budaya Denpasar. Pada 1993 ia menggelar dua kali pameran bersama yaitu, pameran serangkaian HUT PSSRD Universitas Udayana yang ke-10 serta pameran bersama Master-Student, serangkaian Peksiminas di STSI Denpasar. Setahun kemudian Supena kembali mengikuti pameran PKB di Taman Budaya Denpasar serta melaksanakan pameran bersama di Gallery Puri Bukit Mas, Peliatan Ubud. Setelah itu pada 1995 ia menggelar pameran bersama "Group 14" di Art Center Denpasar. Pada 1996 tidak kurang dua event pameran bersama ia ikuti, yaitu pameran bersama HMJS PSSRD Universitas Udayana di Museum Sidik Jari Denpasar serta pameran bersama kelompok "Galang Kangin" di Museum Bali.

Pada 1997 Supena mengikuti empat kali pameran bersama, Philip Moris1997 di Museum Arma. Masih dalam ajang yang sama Supena mengikuti pameran bersama para finalis Philip Moris di Jakarta. Selanjutnya ia kembali berpartisipasi di ajang pameran PKB di Art Center Denpasar. Selain itu, ia juga mengikuti pameran Gelar Seni Lukis 1997 di Art Center Denpasar. Pada 1998 ia mengikuti sebelas kali pameran bersama yang diikuti, yaitu Exhibition 21 di Gallery Sahadewa Batuan, Wort Art di Art Center Denpasar Bali, pameran bersama di Gallery Ch. Fahrenhorst Helmeln Jerman, pameran bersama di Collection of the place Bandung, pameran di The Chedi Payangan, pameran sketch dan Drawing di Art Center Denpasar, pameran Refleksi 1998 di Darga Gallery Sanur, pameran di Duta Fine Art Jakarta dan pameran Philip Moris 1998 di Gallery Nasional Jakarta. Selama 1999 Supena menggelar empat kali pameran bersama, yaitu pameran Koleksi, Museum Sidik jari, pameran di Museum Fur Volkerkunde, Frankrut Jerman, pameran bersama " 40 " besar Indonesia, Windos/Newton di Gallery Widayat, Pameran \& Perupa Bali di TMI Jakarta.

Pada 2000 Supena menghadirkan tiga kali pameran bersama, yaitu Millenium Exhibition SDI di Museum Neka Ubud, Refleksi Seni II di Darga Gallery Sanur, Landscape Art Weitkulturen, Frankrut Jerman. Setelah itu, pada 2001 Supena mengikuti empat kali pameran bersama, yaitu pameran Narcicisme di Museum Sidik Jari Denpasar, pameran Philip Morris Art Award 2001 di Gallery Nasional Jakarta, pameran Cine and Clour di Art Center Denpasar, pameran BaliInsel der geother moerfelden di Walldort Jerman. Pada 2002 Supena mengikuti tiga kali pameran bersama, yaitu pameran Galang Kangin 2002 di Art Center Denpasar, Workshop Galang Kangin di Tejakula Buleleng, dan pameran Festival Seni Perdamaian di Art Center Denpasar.

Pada 2003 Supena mengikuti empat aktivitas pameran bersama, yaitu In Love with Canvas di Gallery Montik Jakarta, Aestetic and Nature di Griya Santriyan Gallery Sanur, The Silent Painting di Griya Santrian Sanur serta Narasi Abstrak di Gallery Millenium, Jakarta. 
Lima kali pameran bersama diikuti pada 2004. Pameran tersebut, antara lain Journey to Foreign Land di Santriyan Gallery Sanur, Bali Temptation di Sanggam Gallery Yogya dan V Gallery Jakarta, Natah Tanah di Pilar Batu Gallery Ubud. Membaca Tri Hita Karana di Millenium Gallery Jakarta, Supena juga pernah mengadakan pameran patung bersama yang berjudul Konstruksi Patung di Paros Gallery Sukawati, Gianyar. Pada 2005 Supena disibukkan dengan tujuh kali pameran bersama, yaitu Intermezo di Langgeng Gallery Yogyakarta, Power ofmind di Orasis Gallery Surabaya, Pameran Himpunan Pelukis Gianyar di Gallery Astra Jakarta atau Hotel Niko Jakarta, Pameran Serupa di Griya Santriyan Sanur, "Bali Bienale" di Arma Museum Ubud.

Sepanjang 2006 Supena mengikuti tiga kali pameran bersama, yaitu Beving Realisme di V Gallery Yogyakarta, Triumph and Deafeat bersama kelompok Galang Kangin di Santrian Gallery Sanur, Spirit of Bali di Damping Gallery Ubud. Pada 2007 pameran yang diikuti, antara lain Triumph and Deafeat bersama Galang Kangin di Taman Budaya Yogyakarta. Thousand Mystery of Borobodur di Jogja Gallery Yogyakarta, White Painting di Santrian Gallery Sanur, Portofolio di Jogja Gallery Yogyakarta, Love Leather di Tony Raka Mas Ubud, Shadow of Prambanan di Jogja Gallery.

Pada 2008 Supena mengikuti tiga kali pameran bersama, yaitu 100 tahun Kebangkaitan Nasional di Jogja Gallery, Entitas Nurani Art Center Denpasar, Bal Art Now Hibilding Jogja Gallery. Tiga kali pameran bersama dilaksanakan pada 2009, yaitu Fresh 4 You di Jogja Gallery, Expectation bersama Galang Kangin and friends di Toni Raka Mas Ubud, serta pameran ilustrasi kompas di Bentara Budaya Jakarta. Pada 2010 Supena hingga saat penelitian ini ditulis sudah melaksanakan tiga kali pameran bersama, yaitu Singapadu A Vilage Creates It Self bersama perupa Singapadu, Return toAbstraction di Tony Raka Ubud, serta "KUTA" pameran bersama Galang Kangin di Gaya Fushion Art Space Ubud. Tak hanya malang-melintang di dunia pameran lukisan ataupun patung, Supena merupakan perupa yang selalu mengembangkan gagasan-gagasannya ke bentuk-bentuk ekspresi rupa yang lain. Instalasi dan performance art juga sering digeluti Supena.

Pada 1995 Supena dan kawan-kawannya semasa kuliah di PSSRD Unud pernah menggarap proyek instalasi Eksperimental Art di UNS, Solo. Kemudian pada 1998 ia pernah menggarap instalasi bertajuk black and white bersama kelompok (STBC, Mukti) di Art Center Denpasar serta menggarap performance art yang bertajuk Taman Sri Wedari bersama kelompok (STBC Mukti) di Sahadewa Gallery Batuan.

Pada 2004 ia menggarap performance Doa pada Laut (Jala Art) di panta Serangan Badung. Pada 2005 Supena bersama Suklu dan Polenk Rediasa, mengarap instalasi bertajuk "Ritus Totem Stimulus" di area Sector Golf Sanur, kemudian masih pada 2005 Supena adalah salah satu partisipan dalam proyek performance Nyoman Erawan yang berjudul Maha Pralaya serta Megalitichum Quantum di GWK Badung, serta proyek instalasi RTRWP kolaborasi bersama kelompok Galang Kangin dan bunyi batu di rumah Buku Cengkilung Denpasar. Pada 2006 Supena bersama kelompok Galang Kangin merayakan 10 tahun berdirinya kelompok ini dengan menghadirkan instalasi 1000 pamer di RBC Cengkilung Denpasar.

Supena merupakan perupa Singapadu yang dikenal sebagai perupa yang intens menghadirkan representasi alam dalam karya-karyanya. Ia lebih dikenal sebagai perupa abstrak dengan representasi alam sebagai indentitas personalnya. Namun, sebagai perupa yang selalu bergerak dalam pencarian karya, Supena tidak hanya berhenti pada bentuk abstrak saja tetapi juga berkarya dengan menghadirkan ikon-ikon seni tradisi dan representasi obyek dengan pendekatan realistik, khususnya pada karya dalam seri emosinya.

Berdasarkan pemaparan pada bab sebelumnya yang membahas Supena dari sisi biografis, konsep karya, proses kreatif, periodisasi, serta pembacaan teks dan konteks karya Supena maka dapat disimpulkan beberapa hal sebagai berikut.

Biografi I Made Supena. Secara biografis Supena terlahir dari keluarga seniman yang mewarisi bakat kesenian sang ayah, I Ketut Muja, seorang pematung otodidak. Saudara-saudara Supena yang lain, seperti Wayan Jana dan I Ketut Sugantika Lekung, serta adik iparnya, Ni Nyoman Sani, juga menekuni dunia kesenirupaan baik sebagai pelukis maupun pematung yang ikut meramaikan kancah seni rupa Bali. Sebagi seorang perupa akademis yang menepuh pendidikan formal kesenirupaan di PSSRD Unud pada 1991-1997, Supena menjadi salah satu perupa Bali yang telah berpengalaman di dunia seni rupa Bali, bahkan di Indonesia. Tidak kurang dari sembilan kali pameran tunggal ia jalankan, mulai dari Bali, Jakarta, Yogyakarta hingga Jerman. Ia juga melakukan tidak kurang lima puluh delapan kali pameran bersama selama rentan waktu 1991 hingga sekarang.

Konsep Karya I Made Supena. Secara konseptual Supena menghadirkan karya-karya yang berasal dari kegelisahan yang dirasakan dari dalam dirinya terhadap suatu obyek ataupun fenomena sosial. Konsep karya Supena bergerak antara menghadirkan representasi alam dalam bungkusan formalistik estetis, terutama pada karya-karya abstraknya, serta menghadirkan represenatasi sosial pada karya seri emosinya. Ia juga sering menghadirkan karya tradisi yang secara konseptual merupakan bentuk kerinduan personalnya terhadap penjelajahan estetis terutama karakter garis pada karya-karya lukis tradisi.

Proses kreatif I Made Supena. Proses kreatif Supena berawal dari ide yang "mengganggu" dan menggelitik naluri estetisnya kemudian ia visualisasikan ke dalam karya-karya sketsa sebagai sebuah studi rupa, baik tentang alam maupun representasi sosial, kemudian dieksekusi di atas kanvas ataupun kayu. Melalui proses kreatifnya, Supena tidak hanya menghadirkan karya dua dimensi, tetapi 
juga merambah seni rupa tiga dimensi, berupa patung yang kerap direpresentasikan bersamaan dengan karya lukisannya, sehingga menjadi sebentuk karya instalasi. Ketertarikan Supena pada karya seni patung dilatarbelakangi oleh garis keturunan sang ayah yang seorang pematung serta latar belakang pendidikan menengahnya, yaitu SMKN 2 Sukawati, yang mengambil Jurusan Seni Kriya Kayu. Kondis tersebut menjadikan ia dan patung memiliki hubungan personal yang erat. Supena juga sering menghadirkan karya yang digali dari khasanah kosa rupa tradisi.Hal ini didorong oleh kekaguman dirinya atas karya-karya I Gusti Nyoman Lempad.

\section{Periodisasi Karya I Made Supena.}

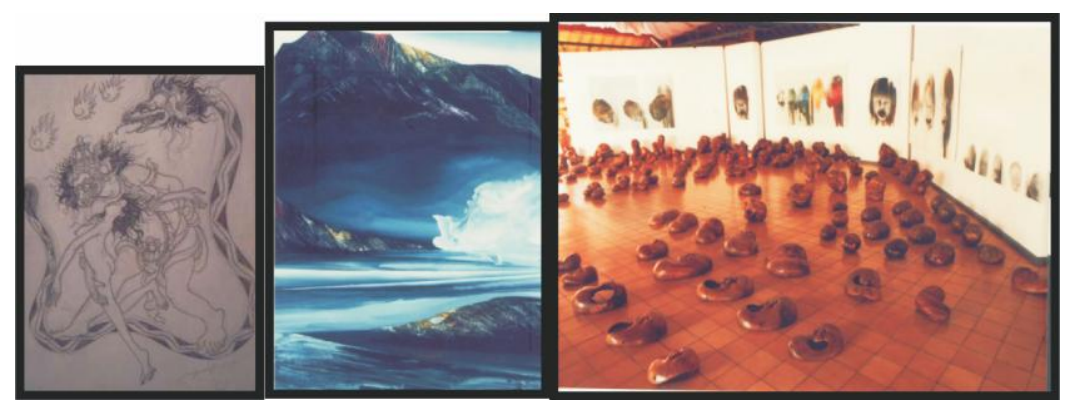

Gambar 1. Pertemuan Ibu Pertiwi, Mengenang Kedalaman, Emosi, Tinta di atas Kertas, Akrilik pada Kanvas, Kayu Suar, Kayu Sonokling, Kayu Kamboja, 32 × 24 cm, 120 x $180 \mathrm{~cm}$, Sumber: Pameran Tunggal, Geneologi I Made Supena, di Jogja Gallery.

Supena adalah perupa yang selalu bergerak dalam pencarian-pencarian gagasan. Selama dua puluh tahun kekaryaannya di dunia seni rupa, Supena telah melahirkan ratusan karya yang secara umum dapat dikelompokan dalam tiga periodisasi, yaitu tradisi, formal, dan emosi. Namun, periodisasi ini diakui Supena bukanlah pengelompokan secara retrospektif yang dapat dibagi dalam waktu tetapi tiap-tiap periodisasi selalu datang silih berganti secara ulak-alik sesuai kerinduan dirinya untuk berkarya dalam tiga kecenderungan tersebut.

Dalam periode tradisi, karya-karya Supena menghadirkan seni lukis wayang tradisi yang bertujuan sebagai upaya Supena untuk memahami persoalan garis yang menarik dalam seni lukis tradisi. Kecenderungan ini terkait dengan karakteristik garis yang konstan dan kuat, seperti yang terlihat pada karya-karya I Gusti Nyoman Lempad yang sangat dikagumi Supena. Dalam periode formal, Supena menghadirkan gubah rupa abstrak yang merupakan representasi alam yang dibungkus dengan kaidah-kaidah estetika formal. Dalam periode emosi Supena menghadirkan representasi sosial melalui penghadiran obyek bayi yang merupakan representasi atas maraknya fenomena sosial, seperti bunuh diri di kalangan anak-anak, mahalnya biaya pendidikan dan kesehatan, serta fenomenafenomena yang kerap muncul mengusik batinnya.

Pembacaan Karya I Made Supena Teks dan Konteks. Teks adalah kombinasi tanda-tanda, baik verbal maupun visual. Hardiman (2010: 12) menyatakan bahwa teks dalam penggunaan sehari-hari menunjuk pada tulisan dalam berbagai bentuknya, seperti buku dan majalah. Akan tetapi, dalam kajian budaya (cultural studies) telah menjadi sebuah aksioma bahwa teks merupakan segala sesuatu yang menghasilkan makna melalui praktik pemaknaan. Dengan demikian pakaian, citra, peristiwa, olahraga, bintang pop, dan lain-lain dapat dibaca sebagai teks.

Dalam sebuah karya seni rupa teks-teks hadir dalam citraan visual. Teksteks tersebut dapat saja hadir sebagai bentuk representasi dari suatu narasi yang sangat berjarak dengan teks tersebut, bahkan ia dapat berbicara tentang persoalan di luar kesenirupaan. Hal inilah yang dapat dimaknai sebagai konteks dalam sebuah karya seni rupa.

Karya seni rupa dalam kehadirannya selalu membawa muatan. Muatan tersebut dapat berupa muatan tekstual dan kontekstual. Muatan tekstual adalah kandungan isi sebuah karya yang didalamnya menyangkut hal-hal yang bersifat estetis. Dalam muatan tekstual sebuah karya hadir sebagai ungkapan murni, yang mempersoalkan unsur-unsur rupa itu sendiri, misalnya garis, warna, bidang, tekstur, volume, komposisi, keseimbangan, serta kesatuan. Dalam muatan tekstual sebuah karya seni hadir tanpa pretensi untuk menyampaikan pesan di luar persoalan seni rupa.

Sementara itu, muatan kontekstual merupakan kandungan karya seni rupa yang berupa pesan atau narasi, yang ada di balik sebuah karya rupa. Dalam wilayah ini sebuah karya rupa tidak hanya berhenti pada ungkapan estetis, tetapi sekaligus membawa pesan atau narasi di luar persoalan seni rupa. Akibatnya, karya seni rupa hadir sebagai representasi atas persoalan di luar seni rupa yang menyeret ke dalam pemaknaan. Karya seni rupa pada akhirnya tidak berhenti dalam sifatnya yang reflektif.

Dalam beberapa karya Supena, kedua muatan tersebut hadir secara bersamaan tetapi ada beberapa karyanya yang murni sebagai ungkapan tekstual yang menyangkut formalisme estetis didalamnya. Dalam sub bab ini penulis mencoba membaca beberapa karya Supena terkait dengan nilai teks ataupun kontekstualnya. Karya-karya Supena dalam ketiga kecenderungan periodisasi yakni tradisi, formal, dan emosi 


\section{Periodisasi Tradisi}

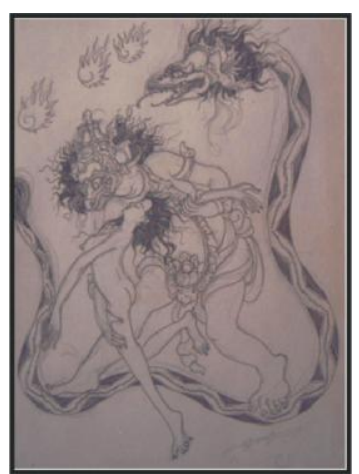

Gambar 2. Pertemuan Ibu Pertiwi

Tinta pada Kertas, 32 × $24 \mathrm{~cm}, 2002$.

Sumber: Katalog Pameran Tunggal, Geneologi I Made Supena, di Jogya Gallery

Pertemuan Ibu Pertiwi (2002) merupakan karya Supena yang menghadirkan karakteristik seni lukis tradisi Bali. Dalam karya tersebut garis menjadi kekuatan utama, tarikan garis yang konstan dan terkontrol menjadi karaktristik karya tersebut yang Supena adopsi dari Gusti nyoman Lempad. Karya ini memisualisasikan sosok Dewa Wisnu yang menjelma menjadi siluman Babi bertemu dengan Dewi Pertiwi. Pertemuan kasih antara keduanya ini kemudian melahirkan sosok raksasa Boma. Karya ini adalah bentuk visualisasi yang menggiring makna kontekstual tentang kesuburan, yakni bertemunya sosok Purusa dari (Wisnu) dengan sosok Pradana (Pertiwi).

\section{Priodesasi Formal}

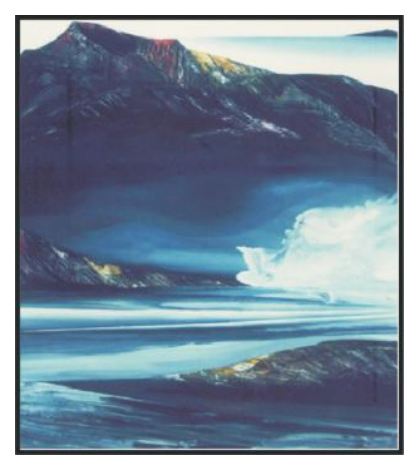

Gambar 3. Mengenang Dalam Kedalaman Akrilik pada Kanvas, 180 x 120 cm, 2007

Sumber Foto: Katalog Pameran Tunggal, Geneologi I Made Supena, di Jogja Gallery.
Melalui karya Mengenang Dalam Kedalaman, Supena menghadirkan lanskap gunung yang teramat kontemplatif dan puitik. Ia menghadirkan abstraksi gunung dengan tekstur semu melalui kerokan palet yang terkesan padat dan kuat diantara sapuan awan memutih terkadang membiru menyelimuti gunung menimbulkan kesan meditatif. Ada kedalaman yang dihadirkan secara puitik. Efek abstraksi tersebut dihadirkan dalam balutan background yang flat putih dan terkesan tenang mendukung kedalaman yang hendak ia bangun. Nada warna coba ia hadirkan dengan memberikan aksen-aksen merah dan kuning pada puncak gunung yang memberikan irama visual yang menarik.

\section{Periodesasi Emos}

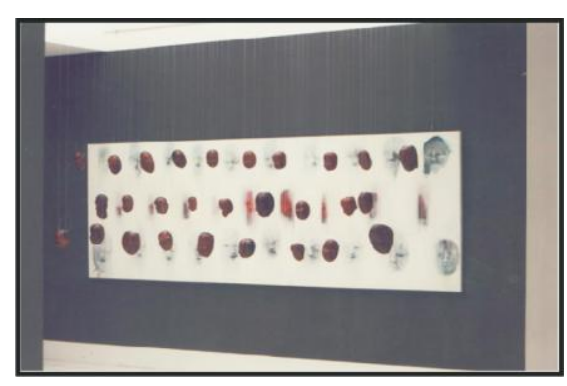

Gambar 4. In The White,

Akrilik pada kanvas, 150 x $400 \mathrm{~cm}$ dan 26 patung, 2009

Sumber Foto: Proposal Pameran Tunggal, Geneologi I Made Supena, di Jogja Gallery.

In The White (2009) merupakan karya Supena yang menghadirkan presentasi lukisan dan patung-patung. Patung-patung kepala bayi yang berjumlah dua puluh enam buah bergelantungan di depan bidang kanvas berukuran 150 x 400 $\mathrm{cm}$ yang juga menghadirkan wajah-wajah bayi yang cenderung abu-abu yang monochrome tersapu oleh latar putih flat yang bersih. Jarak antara karakteristik tiga dimensional pada patung dengan karakteristik dua dimensional pada lukisan coba untuk dicairkan oleh Supena dalam karyanya. Hal ini menjadikan karya Supena menjadi instalasi lukisan dan patung yang mencoba mempertanyakan batasan-batasan antara seni lukis dan seni patung itu sendiri.

\section{PENUTUP}

I Made Supena adalah perupa yang sudah melalang melintang selama kurang dari 20 tahun berdirinya seni rupa Bali. Secara geografis Supena terlahir dari ayah, I Ketut Muja, seorang pematung yang terkenal. Sementara kakaknya, I Wayan Jana juga merupakan pematung akademis yang pernah menempuh pendidikan di Yogyakarta. Adiknya, I Nyoman Lekung Sugantika, merupakan 
100 imasi, Vol. 12, No. 1, Februari $2014: 85$ - 100

seorang pelukis Jurusan ISI Denpasar, sedangkan iparnya, Ni Nyoman Sani, juga seorang pelukis.

Konsep karya Supena beranjak dari persoalan alam yang dituangkan dalam karya-karyanya. Proses kreatif I Made Supena ditandai oleh periodisasi karyanya yakni tradisi, formal, dan emosi. Sedangkan karya Supena dapat dibaca dalam persepektif teks rupa melalui kuatnya unsur-unsur formal dalam karyanya

Karya Supena juga dapat dibaca konteksnya sebagai sebuah pemaknaan terhadap obyek ataupun teks-teks rupa yang dihadirkan.

\section{KEPUSTAKAAN}

Bugin, Burhan (Ed.). 2004. Metode Penelitian Kualitatif: Aktualisasi Metodologis ke Arah Ragam Varian Kontemporer. Jakarta: PT Raja Grafindo Persada.

Bugin, Burhan. 2005. Analisis Data Penelitian Kualitatif.Jakarta:Grafindo

Freitag, U Thomas, 1999. Reality of Abstract Painting I Made Supena. Bali: PT Dian Rakyat.

Hardiman. 2010. I Made Supena genealogi:Katalog Pameran Tunggal. Yogyakarta: Jogja Gallery.

Sukra, I Wayan. 2005. Katalog Pameran Serupa. Bali: Satrian Gallery.

Supena, I Made, dkk. 2009. Singapadu A Village Creates it Self. Bali: Santrian Gallery. 